\title{
Risks of social relations ecological assimilation process
}

\author{
Aleksandr Strebkov*, Gazimagomed Gazimagomedov, Abdurashid Musaev, Andrei \\ Aleinikov, and Artem Sunami \\ St. Petersburg State University, St. Petersburg, Russia
}

\begin{abstract}
Nature is the essential life-giving condition for the humans and their activity. And this fact as no other implies sustainable management of the natural potential in order to produce and meet human needs. Ever more increasing importance of the ecological relations and their transformation into the autonomous relations and, therefore the establishment of their impact on the other social relations and subsequent submission of the social relations to the ecological ones, turns into the irreversible process which means that the ecological relations demand their inclusion in the industrial and property relations. Nonetheless, this process of the ecological assimilation proceeds controversially. The battle over the environmental agenda does not subside and this is the evidence of the interdisciplinary conflict, subject matter of which is the state of the environment that is predetermined by the competitive modes of cooperation which are natural for the free-market economy. The containment of the industrial relations' ecological assimilation process from the market and state accelerates consolidation of the general public in their resistance to this tendency which results in the reduction of the environmental risks and disasters as their logical manifestation.
\end{abstract}

\section{Introduction}

Environmental agenda did arise not today or yesterday but well before our time, namely when a shovel was replaced by highly productive mechanized means of labor, when humanity turned science into such a productive force which allowed it not only to take nature-made ready to be used products from the nature but also synthesize new materials which were not created by it. This revolution in human environmental interactions has constituted various relations, attributable primarily to property relations, in different eras throughout its history. Industrial production, and with it industrial relations shift focus to the crafted means of production and after becoming a basic element of property predetermined all the battles of the capitalist dominance. Nature has become the pantry of industry while in its anarchy of human exposure it begins to defer to consciously designed environment that is already affected by vagaries of nature. Large-scale impacts on the nature led to negative repercussions for the very nature and for a human alongside with it.

\footnotetext{
* Corresponding author: strebkov.com@mail.ru
} 
For example, the new Intergovernmental Panel on Climate Change (IPCC) report indicated that atmospheric CO2 concentrations in 2019 were higher than at any time in 2 million years, temperatures during the most recent decade exceeded those of the most recent multi-century warm period, around 6,500 years ago; global mean sea level has risen faster since 1900, than over any preceding century in the last 3,000 years. Over the next 20 years, global temperature is expected to reach or exceed $1.5^{\circ} \mathrm{C}$ of heating [1] which will cause an increasing occurrence of extreme sea level events that can occur at least annually at more than half of tidal gauge locations by 2100 while the Arctic is likely to be practically ice-free in September at least once before 2050 [2].

Ecology, value of which is socially recognized whereas respect for the environment is established, is becoming crystallization of the public's moral requirements both for the economy and politics. Ecological assimilation of the social relations is the prospective trend which prejudges the "social construct" of the socialized humanity [3].

\section{Materials and methods}

The process of the ecological relations' incorporation into the industrial relations has not been finished neither in the particular communities nor in the world at large as have not been finished natural calamities which are the result of the human active interference in the life of nature. Environmental disasters that are dependent to a greater or lesser extent on human, are repeating themselves on an ongoing basis. These aspects of the relationships of humanity and nature are highlighted in the research papers of contemporary foreign authors, such as S.H. Nelson [4], A. Huber, S. Gorostiza, P. Kotsila, M.J. Beltrán and M. Armiero [5], A.M. Stoner [6], C.E. Sica [7], C. Morinville and N. Van Lier [8], M.J. DeBoom [9], D. Faber [10], S. Schindler and F. Demaria [11], J. Szabo [12] and also domestic researchers such as M.N. Vlasenko and Yu.N. Shedieko [13] et al.

Yet incompleteness of the ecological assimilation process is coupled with the conflictual interaction risks of the ecological relations' entities i.e. State, business and citizens and as A. Huber and other coauthors of the aforementioned scientific article claim that "...power relations, economic pressures and profit influence "risky" dam management decisions, often disregarding the vernacular knowledge of concerned communities and silencing critical voices..." [5]. Conflict between the entities of the environmental relations inevitably poses casualty risks to these entities' economic, social and political positions and the severity and imminence of the risks do hinge on the extent of this confrontation. In view of this, conflict approach in the analysis of the industrial relations' ecological assimilation is considered to be most fruitful.

\section{Study outcomes and discussion}

Humanity does not expect bounties from the nature but instead humanity takes them from it although on a scale far greater that it is physiologically and socially essential if we make calculations based on the consumption which is unburdened by the capitalist exploitation of the natural resources and labour force. Scientists estimate that today foodstuff is produced twice as much as is necessary [14]. Almost 2 billion of grown and produced food on the earth per year, which is up to $30-50 \%$, is not being consumed. At the same time every eighth on the planet (12\%) malnourished during 2018. In Russia $8 \%$ of the population has admitted to the scarcity of food [15]. For example, United States discards nearly 40 million tons of food every year, representing up to 30-40 percent of the entire US food supply and costing the country around 218 billion dollars per year. Meanwhile 35 million people across USA (12\%), including 10 million children, are suffering from the food insecurity. Food 
wasting has irreversible environmental effects as it wastes the water and energy resources it took to produce and generates greenhouse gases up to 11 percent of the world's emissions [16].

This greatest catastrophe in which hundreds of millions of people die all over the world is the result of the free market reign, the greatest competition shaped on the food market. And the State is to blame for the fact that the agricultural business of the developed countries destroys agricultural production of the developing countries where famine is people's constant life companion. "Observers take note that subsidies to European and American farmers is a veritable scourge for developing countries, especially for Africa" [15]. States with the developed economies maintain domestic business by setting all the political stage for its dominance in the global food markets. And in this case we can hardly agree with the foreign authors who seek on the basis on the analysis of the particular dam disasters - Vajont (Italy) and Ribadelago (Spain), induce public consciousness to debunking "the apolitical notion of "socially constructed disasters" rather than speculating about "capital-driven destructions" [5]. Beyond "socially constructed disasters" lies not repoliticizing of the debates around the man-made or indeed not the re-politicizing of anything but the abolishment of that base on which capitalism rests as ever that is the competition which gives rise to a false and not actual rationalization. "...The truth is that an adequate food supply is produced in the world, as it was noted at the XXIV International Union of Food and Supporting Industries congress in 2002, to satisfy 6 billion people and at the same time thousands of kids are starving to death. This is not the technical issue but rather political. It is the issue in the disproportional food distribution and not the issue of the insufficient food production" [15]. The two entities of the ecological relations business and State, particularly in the developed countries, are in close alliance and make every endeavor not to politicize ecological relations but to provide them with separate existence and by doing so to rid themselves of the responsibility towards citizens of both their own country and the rest of the world. Thereby the blame for the various natural or man-made hazards is shifted on to either single representatives of a particular business or State officials that do not cope with the risks and cannot prevent possible disasters. While it is the States, especially in the developed countries, who are the spokesmen for the total capital interests and this fact makes them already fully responsible for the actions of business and its catastrophic consequences.

Market relations cannot incorporate in themselves environmental relations. Market rationality is beyond ecology and is even alien to it. Hence Sara H. Nelson does not talk about the market rationality towards the nature and assumes that "rationalizing environmental values was not simply about applying market rationality to the natural world, but entailed reexamining the nature of that rationality itself and its relevance to social behavior" [4]. The search of the new meanings in actual relations is the lot of consciousness which cannot accept the existing reality but also expects to find a meaning which far from reality in order to view reality in even more illusory way giving environmental relations more autonomy which is independent from market and modern political constructions created by that same market. Market rationality takes precedence over the environmental values' rationality by turning emissions and environmental pollution in the area of "the financial gain only" [17]. Market is not in rush to incorporate environmental relations or give them the leading role since capital is getting natural resources at no cost. In social terms it is not the nature that determines any profit of any business but it is the business profit which determines the attitude towards the nature and those effects of the reverse impact of the nature on a human. Therefore disasters, and that are the environmental risks in its real manifestation, are the result of the so-called "social constructing" and it is the unfortunate but inevitable and typical result for the industrial relations which are not striving to incorporate environmental relations in themselves. 
State-business alliance confronts third entity - the public, that suffers from the environmental calamities and is unable to cope without the State-business support. However, at times this assistance from the state appears as mockery. Russian State comes to the rescue with 10,000 rubles of compensation for those citizens who were affected by fire and had property destroyed. Notably, Russian State acts even more cynically towards the Russians who died from vaccination during Covid-19 pandemic by paying 30,000 rubles of compensation to the relatives of the deceased [18]. But the more solid statebusiness alliance and more distinctively shaped their common interest in giving an autonomous character to environmental relations is, which means that the state of environment is recognized as not a political issue, the more active the public movement for preservation of the environment in its original form and its politicization is. Thus, establishment of the construction debris landfill in Shies of the Arkhangelsk region and the authorities tenacity in the implementation of their decision led to "...the rise of the interregional environmental coalition "Stop Shies" which was joined by 36 movements from Arkhangelsk, Vologda regions and Komi Republic [19]. This kind of civil society organization against State-business consolidated interests is common not only for Russia, as a result of which it can be observed slow but permanent strengthening of the intersocietal environmental movement which is blending into general social movement for the ecological civilization [20].

\section{Conclusions}

Capitalist exploitation of the natural world, in which competition is the primary interaction form of the economic agents, strives to maintain environmental relations over the side of the industrial relations as long as the risks arising from the competition had not become this obvious fact although they are increasingly manifesting themselves in the natural and manmade hazards. As long as competition or conflict determine social visage of the nations and peoples and their social soul filled with the desire for enrichment, environmental relations will be self-contained despite how voluntarily business attempts to include them within the rage of its liability and as much as the state seeks to legitimize them and environmental movements exercise public scrutiny. Environmental relations' self-reliance will not benefit them but only to the detriment of them. Excluded from the industrial relations, they become sporadically updated and develop only from one environmental event to another receiving bigger and smaller support from business, State and public. It can be stated that if the formal recognition of the need for the strengthening of the environmental relations at the State level and level of inter-State agreements is fulfilled, then it is done with difficulty and there is no such power that would coerce the business, especially large business, which could even be part of a corporate social responsibility pool, into meeting all the environmental conservation's requirements.

\section{Acknowledgements}

The study was carried out by a grant from the Russian Science Foundation (project No. 1918-00115) and with the financial support of the Russian Foundation for Basic Research (project no. 20-011-00393. 


\section{References}

1. United Nations UN News Global perspective Human stories, https://news.un.org/

2. BBC NEWS, https://www.bbc.com/

3. Z. Yunfei, Capitalism Nature Socialism, 30(1), 11 (2019)

4. S. H. Nelson, Capitalism Nature Socialism, 28(1), 118 (2017)

5. A. Huber, S. Gorostiza, P. Kotsila, M. J. Beltrán, M. Armiero, Capitalism Nature Socialism, 28(3), 48 (2017)

6. A. M. Stoner, Capitalism Nature Socialism, 32(2), 77 (2020)

7. C. E. Sica, Capitalism Nature Socialism, 31(4), 34 (2020)

8. C. Morinville, N. Van Lier, Capitalism Nature Socialism (2021)

9. M. J. DeBoom, Annals of the American Association of Geographers, 111(3), 900 (2021)

10. D. Faber, Capitalism Nature Socialism, 31(4), 1 (2020)

11. S. Schindler, F. Demaria, Capitalism Nature Socialism, 31(4), 52 (2020)

12. J. Szabo, Capitalism Nature Socialism (2020)

13.M. N. Vlasenko, Yu. N. Shedko, Business Strategies, 2, 21 (2017)

14. Twice as much food as it needed is produced in the world, https://animalworld.com.ua/

15.How many people are suffering from hunger in the world. Mortality from famine, https://fkrchr.ru/

16. Food Waste in America in 2021: Statistics + Facts, https://www.rts.com/

17. A. Vlachou, G. Pantelias, Capitalism Nature Socialism, 28(2), 84 (2017)

18. RBC, https://www.rbc.ru/

19. What does the example of Shies teach, https://www.vedomosti.ru/

20. A. Gare, Capitalism Nature Socialism, 32(1), 37 (2021) 